\title{
miR-17-92 expression in differentiated T cells - implications for cancer immunotherapy
}

Kotaro Sasaki ${ }^{1,2+}$, Gary Kohanbash ${ }^{5,6+}$, Aki Hoji ${ }^{3,5}$, Ryo Ueda ${ }^{3,5}$, Heather A McDonald ${ }^{5}$, Todd A Reinhart ${ }^{6}$, Jeremy Martinson ${ }^{6}$, Michael T Lotze ${ }^{4}$, Francesco M Marincola ${ }^{7}$, Ena Wang ${ }^{7}$, Mitsugu Fujita ${ }^{3,5}$, Hideho Okada $2,3,4,5^{*}$

\begin{abstract}
Background: Type-1 T cells are critical for effective anti-tumor immune responses. The recently discovered microRNAs (miRs) are a large family of small regulatory RNAs that control diverse aspects of cell function, including immune regulation. We identified miRs differentially regulated between type- 1 and type- $2 \mathrm{~T}$ cells, and determined how the expression of such miRs is regulated.

Methods: We performed miR microarray analyses on in vitro differentiated murine T helper type-1 (Th1) and T helper type-2 (Th2) cells to identify differentially expressed miRs. We used quantitative RT-PCR to confirm the differential expression levels. We also used WST-1, ELISA, and flow cytometry to evaluate the survival, function and phenotype of cells, respectively. We employed mice transgenic for the identified miRs to determine the biological impact of miR-17-92 expression in T cells.
\end{abstract}

Results: Our initial miR microarray analyses revealed that the miR-17-92 cluster is one of the most significantly over-expressed miR in murine Th1 cells when compared with Th2 cells. RT-PCR confirmed that the miR-17-92 cluster expression was consistently higher in Th1 cells than Th2 cells. Disruption of the IL-4 signaling through either IL-4 neutralizing antibody or knockout of signal transducer and activator of transcription (STAT)6 reversed the miR17-92 cluster suppression in Th2 cells. Furthermore, T cells from tumor bearing mice and glioma patients had decreased levels of miR-17-92 when compared with cells from non-tumor bearing counterparts. CD4 ${ }^{+} \mathrm{T}$ cells derived from miR-17-92 transgenic mice demonstrated superior type-1 phenotype with increased IFN- $\gamma$ production and very late antigen (VLA)-4 expression when compared with counterparts derived from wild type mice. Human Jurkat T cells ectopically expressing increased levels of miR-17-92 cluster members demonstrated increased IL-2 production and resistance to activation-induced cell death (AICD).

Conclusion: The type-2-skewing tumor microenvironment induces the down-regulation of miR-17-92 expression in $T$ cells, thereby diminishing the persistence of tumor-specific $T$ cells and tumor control. Genetic engineering of $T$ cells to express miR-17-92 may represent a promising approach for cancer immunotherapy.

\section{Background}

We have focused on the development of effective immunotherapeutic strategies for central nervous system (CNS) tumors, such as glioblastoma multiforme (GBM). Preclinical studies have demonstrated that tumor-specific T helper type-1 (Th1) and T cytotoxic type-1 (Tc1) cells, but not type- 2 counterparts, can efficiently traffic into CNS tumor sites and mediate effective therapeutic efficacy, recruited via the type-1 chemokine CXCL10

\footnotetext{
* Correspondence: okadah@upmc.edu

† Contributed equally

${ }^{2}$ Department of Immunology, University of Pittsburgh School of Medicine, 200 Lothrop Street, Pittsburgh, PA, 15213, USA
}

[1-3] and the integrin receptor, Very Late Antigen (VLA)-4 [4-7]. Despite the importance of the type-1 T cell response, cancers, including GBMs, secrete numerous type- 2 cytokines [8-10] that promote tumor proliferation [11,12] and immune escape [13]. Hence, the strategic skewing of existing type- 2 to type- 1 immunity in glioma patients may be critical for the development of more effective immunotherapy.

MicroRNAs (miRs) are a novel class of endogenous small single-stranded RNA molecules which are 18-24 nucleotides in length [14]. Mature miRs repress mRNA encoded protein translation and are highly conserved between species, including viruses, plants and animals
C Biomed Central

() 2010 Sasaki et al; licensee BioMed Central Ltd. This is an Open Access article distributed under the terms of the Creative Commons Attribution License (http://creativecommons.org/licenses/by/2.0), which permits unrestricted use, distribution, and reproduction in any medium, provided the original work is properly cited. 
[15]. There are over $700 \mathrm{miRs}$ identified in the human genome that collectively are predicted to regulate twothirds of all mRNA transcripts [14]. Findings over the past several years strongly support a role for miRs in the regulation of crucial biological processes, such as: cellular proliferation [16], apoptosis [17], development [18], differentiation [19], metabolism [20], and immune regulation $[21,22]$. We recently reported that miR-222 and -339 in cancer cells down-regulate the expression of an intercellular cell adhesion molecule (ICAM)-1, thereby regulating the susceptibility of cancer cells to cytotoxic T lymphocytes (CTLs) [23]. This is among the first reports to demonstrate the role of $\mathrm{miR}$ in cancer immunosurveillance.

In the current study, in an effort to understand the potential roles of miRs in anti-tumor immunity, we examined miRs differentially expressed in Th1 and Th2 cells. Our miR microarray and RT-PCR analyses revealed that of all analyzed miRs, members of the miR-17-92 cluster (miR-17-92) are of the most significantly overexpressed miRs in murine Th1 cells when compared with Th2 cells. The miR-17-92 transcript encoded by mouse chromosome14 (and human chromosome 13) is the precursor for 7 mature miRs (miR-17-5p, miR-17-3p, miR18a, miR-19a, miR-20a, miR-19b and miR-92) [24,25]. This cluster is also homologous to the miR-106a-363 cluster on the X chromosome and the miR-106b-25 cluster on chromosome 5 . Together, these three clusters contain $15 \mathrm{miR}$ stem-loops, giving rise to 14 distinct mature miRs that fall into $5 \mathrm{miR}$ families. The members in each family have identical seed regions. This genomic organization is highly conserved in all vertebrates for which complete genome sequences are available [26].

miRs in the miR-17-92 cluster are amplified in various tumor types, including B cell lymphoma and lung cancer, and promote proliferation and confer anti-apoptotic function in tumors, thereby promoting tumor-progression [27-31]. Knockout and transgenic studies of the miR-1792 cluster in mice have demonstrated the importance of this cluster in mammalian biology [25]. Transgenic mice with miR-17-92 overexpressed in lymphocytes develop lymphoproliferative disorder and autoimmunity but not cancer [24]. These findings demonstrate a critical role for miR-17-92 cluster in $\mathrm{T}$ cell biology.

We show here that miR-17-92 is up-regulated in Th1 cells when compared with Th2 cells. IL-4 and STAT6 signaling mediate the down-regulation of miR-17-92. Tumor-bearing host conditions also suppress the miR17-92 cluster expression in $\mathrm{T}$ cells, which is associated with a loss in ability to produce IFN- $\gamma$. This led us to hypothesize that miR-17-92 cluster overexpression might enhance type- 1 responses. Indeed, type- $1 \mathrm{~T}$ cells derived from miR-17-92 transgenic mice demonstrated a more pronounced type 1 phenotype including enhanced
IFN- $\gamma$ production and increased VLA-4 expression when compared with control type- $1 \mathrm{~T}$ cells. These findings suggest that miR-17-92 plays a critical role in type-1 adaptive immunity.

\section{Materials and methods Reagents}

RPMI 1640, FBS, L-glutamine, sodium pyruvate, 2-mercaptoethanol, nonessential amino acids, and penicillin/ streptomycin were obtained from Invitrogen Life Technologies. Recombinant murine (rm) IL-12 was purchased from Cell Sciences Technologies. RmIL-4, recombinant human (rh) IL-4 and rhIL-2 were purchased from PeproTech. Purified monoclonal antibodies (mAbs) against IL-12 (C15.6), IFN- $\gamma$ (R4-6A2), IL-4 (11B11), CD3 (145-2C11), CD4 (RM4-5), CD8 (53-6.7) and CD49d (R1-2) were all purchased from BD Pharmingen. Purified mAbs against CD3 (UCHT1) and CD28 (CD28.2) and IL-4 (MP4-25D2) were purchased from Biolegend. RT-PCR reagents and primers were purchased from Applied Biosystems and analyzed on a BioRad IQ5. WST-1 reagent was purchased from Roche. For isolation of $\mathrm{T}$ cells, immunomagenic isolation kits from Miltenyi Biotec were used. All reagents and vectors for lentiviral production were purchased from System Biosciences with the exception of Lipofectamine 2000, which was from Invitrogen.

\section{Mice}

C57BL/ 6 mice and C57BL/6 background STAT6 defi-

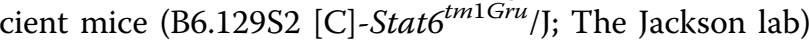
(both 5-9 wk of age) were purchased from The Jackson Laboratory. C57BL/6-background miR-17-92 transgenic (TG) mice (C57BL/6-Gt [ROSA]26Sor tm3(CAG-MIRN17-92,$E G F P) R s k y / J$; The Jackson Lab) were maintained in the Hillman Cancer Center Animal Facility at University of Pittsburgh as breeding colonies and bred to C57BL/6background mice transgenic for $\mathrm{Cre}$ recombinase gene under the control of the Lck promoter (B6.Cg-Tg [Lckcre]548Jxm/J, the Jackson Lab) to obtain mice, in which $\mathrm{T}$ cells expressed miR-17-92 at high levels (miR-17-92 TG/TG). For mouse tumor experiments, C57BL/6 mice and $\mathrm{C} 57 \mathrm{BL} / 6$ background $S T A T 6^{-1-}$ mice received subcutaneous injection of $1 \times 10^{6} \mathrm{~B} 16$ tumor cells resuspended in PBS into the right flank. On day 15 following tumor inoculation, mice were sacrificed and splenic $\mathrm{T}$ cells were isolated. Animals were handled in the Hillman Cancer Center Animal Facility at University of Pittsburgh per an Institutional Animal Care and Use Committee-approved protocol.

\section{T cells from Healthy Donors and Patients with GBM}

This study was approved by the local ethical review board of University of Pittsburgh. All healthy donors and 
patients with GBM signed informed consent before blood samples were obtained. To determine the impact of IL-4, healthy donor-derived $\mathrm{CD}_{4}^{+} \mathrm{T}$ cells were isolated with immunomagentic-seperation and stimulated with $100 \mathrm{IU} /$ $\mathrm{ml} \mathrm{rhIL-2,} \mathrm{anti-CD3}$ and anti-CD28 mAbs $(1 \mu \mathrm{g} / \mathrm{ml}$ for each) in the presence or absence of rhIL-4(10 ng/ml). RTPCR analyses were performed with both healthy donorand patient-derived $\mathrm{T}$ cells to determine the expression of miR-17-92 as described in the relevant section.

\section{Th1 and Th2 Cell Culture}

Th1 and Th2 cells were differentiated from immunomagnetically-separated $\mathrm{CD} 4^{+}$splenic $\mathrm{T}$ cells. Magnetic activated cell separation (MACS) was carried out using positive selection. Briefly, spleens were minced in complete media, resuspended in red blood cell lysis buffer and stained with immunomagnetically labeled anti-CD4 antibody. Cells were then washed and placed through the magnetic column in $500 \mu \mathrm{l}$ of MACS buffer. The column was then washed 3 times with buffer and then removed from the magnet and labeled cells were extracted in $3 \mathrm{ml}$ of MACS buffer.

For differentiation of $\mathrm{T}$ cells, purified $\mathrm{CD} 4^{+}$cells were stimulated in 48 well plates with anti-CD3 mAb $(5 \mu \mathrm{g} /$ $\mathrm{ml}$ ) in the presence of irradiated C57BL/6 spleen cells (3000 Rad) as feeder cells. RmIL-12 $(4 \mathrm{ng} / \mathrm{ml}), \mathrm{rmIFN}-\gamma$ $(4 \mathrm{ng} / \mathrm{ml})$, anti-IL-4 $(10 \mu \mathrm{g} / \mathrm{ml}) \mathrm{mAb}$ and rhIL-2 (100 $\mathrm{IU} / \mathrm{ml}$ ) were added for Th1 development. Th2 cells were generated from the same $\mathrm{CD} 4^{+}$cell precursors stimulated with anti-CD3 $\mathrm{mAb}$ and feeder cells in the presence of rmIL-4 $(50 \mathrm{ng} / \mathrm{ml})$, two anti-IFN- $\gamma$ mAbs (10 $\mu \mathrm{g} / \mathrm{ml})$, anti-IL-12 $\mathrm{mAb}(10 \mu \mathrm{g} / \mathrm{ml})$ and rhIL-2 (100 IU/ $\mathrm{mL}$ ). After 10 days cells were stained for IL-4 and IFN- $\gamma$ to confirm differentiation. Neutral cell culture included anti-CD3, feeder cells and rhIL-2. For studies involving IL-4 blockade, $12.5 \mathrm{ng} / \mathrm{ml}$ anti-human IL- $4 \mathrm{mAb}$ (Biolegend) was used in human experiments and $2.5 \mu \mathrm{g} / \mathrm{ml}$ anti-mouse IL-4 mAb (11B11) in murine studies. IFN- $\gamma$ and IL-4 in the culture supernatants were measured using specific ELISA kits (R\&D Systems). For FACs analysis, cells were incubated with $\mathrm{mAb}$ at $4^{\circ} \mathrm{C}$ for $30 \mathrm{~min}$, washed twice in staining buffer, and fixed in $500 \mu \mathrm{l}$ of $2 \%$ paraformaldehyde in PBS. Cells were stored in the dark at $4^{\circ} \mathrm{C}$ until analysis. Flow cytometry was carried out on the Coulter XL four-color flow cytometer at the flow cytometry core facility of the University of Pittsburgh Cancer Institute.

\section{miR Microarray}

Total RNA was isolated from Th1 and Th2 cells using the Trizol reagent and quality was confirmed with an A260/A280 ratio greater than 1.85 . Two $\mu$ g of total RNA was labeled with either Hy5 (red; Th1) or Hy3 (green; Th2) fluorescent dyes using miRCURY LNA
microRNA labeling kit (Exiqon, Woburn, MA) according to manufacturer's protocol. Labeled miR samples in duplicate were cohybridized on to miR array slides, a custom spotted miR array V4P4 containing duplicated 713 human, mammalian and viral mature antisense microRNA species (miRBase: http://microrna.sanger.ac. uk/, version 9.1) plus 2 internal controls with 7 serial dilutions printed in house (Immunogenetics Laboratory, Department of Transfusion Medicine, Clinical Center, National Institutes of Health) [32]. After washing, raw intensity data were obtained by scanning the chips with GenePix scanner Pro 4.0 and were normalized by median over entire array. Differentially expressed miRs were defined by mean $(n=2)$ fold change (Th1/Th2 signal intensity) $>2$.

\section{Quantitative RT-PCR}

Total RNA was extracted using the Qiagen RNeasy kit and quality was confirmed with a A260/A280 ration greater than 1.85. RNA was subjected to RT-PCR analysis using the TaqMan microRNA Reverse Transcription Kit, microRNA Assays (Applied Biosystems), and the Real-Time thermocycler iQ5 (Bio-Rad). The small nucleolar SNO202 was used as the housekeeping small RNA reference gene for all murine samples and RNU43 for human samples. All reactions were done in triplicate and relative expression of RNAs was calculated using the $\Delta \Delta C_{\mathrm{T}}$ method [33].

\section{WST-1 Proliferation Assay}

For WST-1 proliferation assays, $1 \times 10^{4}$ cells were cultured in a 96 well plate for 24-48 hours in $100 \mu \mathrm{l}$ of complete media. Then, $10 \mu \mathrm{l}$ of WST-1 reagent was added to each well. Cells were incubated at $37^{\circ} \mathrm{C}, 5 \%$ $\mathrm{CO}_{2}$ for 4 hours, and placed on a shaker for $1 \mathrm{~min}$. The plates were then read on a micro plate reader with a wavelength of $420 \mathrm{~nm}$ and a reference at $620 \mathrm{~nm}$.

\section{Assays using Jurkat lymphoma cells transduced with miR-17-92}

Jurkat human $\mathrm{T}$ cell leukemia cells (American Type Culture Collection) were transduced by either one of the following pseudotype lentiviral vectors: 1 ) control vector encoding GFP; 2) the 17-92-1 expression vector encoding miR-17 18 and 19a, or 3) the 17-92-2 expression vector encoding miR 20, 19b-1, and 92a-1. All vectors were purchased from SBI. Lentiviral particles were produced by co-transfecting confluent 293TN cells (SBI) with pPACK-H1 Lentivirus Packaging Kit (SBI) and the miR containing expression vectors (SBI) noted above using Lipofectamine 2000 reagent (Invitrogen). Supernatant was collected after 48 hour incubation at $37^{\circ} \mathrm{C}$ with $5 \% \mathrm{CO}_{2}$ and placed at $4{ }^{\circ} \mathrm{C}$ with PEG-it Virus Concentration Solution (SBI) for $24 \mathrm{hrs}$. Supernatants/PEG 
solutions were then centrifuged and the pellet was resuspended in a reduced volume of media as viral stock. Jurkat cells were further resuspended in the viral stock together with polybrene $(8 \mu \mathrm{g} / \mathrm{ml})$ for $24 \mathrm{hrs}$. Fresh media was then added to the cells and transduction efficiency was evaluated by GFP expressing cells. For IL-2 production, transduced Jurkat cells were stimulated with Phorbol 12-myristate 13-acetate (PMA) (10 $\mathrm{ng} / \mathrm{ml}$ ) and ionomycin $(500 \mathrm{nM})$ for overnight and supernatant was assayed for IL-2 by a human IL-2 ELIZA kit. For activation induced cell death (AICD), cells were treated with $10 \mu \mathrm{g} / \mathrm{ml}$ purified anti-CD3 mAb (UCHT1) from Biolegend for 24 hours and then cell viability was measured using WST-1 reagent.

\section{Statistical Methods}

All statistical analyses were carried out on Graphpad Prism software. The statistical significance of differences between groups was determined using student $\mathrm{t}$ - test. We considered differences significant when $p<0.05$. A post test for linear trend test was used to determine linear trend and we considered $p<0.05$ to be significant.

\section{Results}

miR-17-92 and its paralogs are overexpressed in Th1 cells compared with Th2 cells

To identify differentially expressed miRs between Th1 and Th2 cells, we performed a miR microarray analysis. From mouse splenic CD $4^{+} \mathrm{T}$ cells, Th1 and Th2 cells were generated as described in Materials and Methods. These $\mathrm{T}$ cells exhibited expected cytokine profiles with Th1 cells dominantly producing IFN- $\gamma$ but not IL-4, while Th2 cells produce mostly IL-4 (Fig. 1A). Total RNA was extracted from these T cells, and analyzed for differential miR expression by miR microarray for 714 miRs (Fig. 1B). Hierarchical clustering of differentially expressed miRs revealed distinct miR expression profiles between the Th1 and Th2 cells. Eleven of the miRs from the miR-17-92 cluster and its paralogs were expressed at higher levels in Th1 cells than in Th2 cells. Next, we ranked the miRs preferentially expressed in Th1 cells according to the fold difference of expression when compared with Th2 cells (Fig. 1C). Interestingly, members of miRs in the miR-17-92 clusters were identified as the most differentially expressed of all miRs in
A
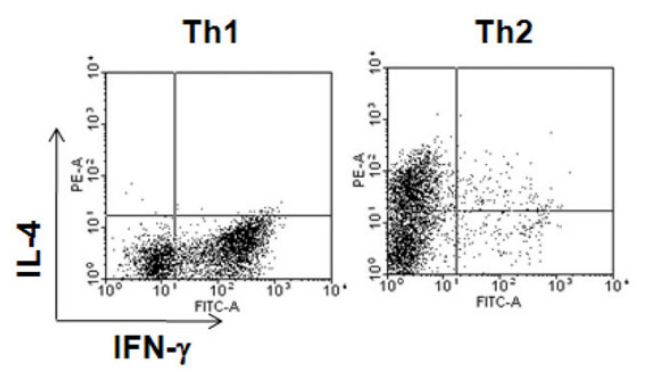

\section{D}

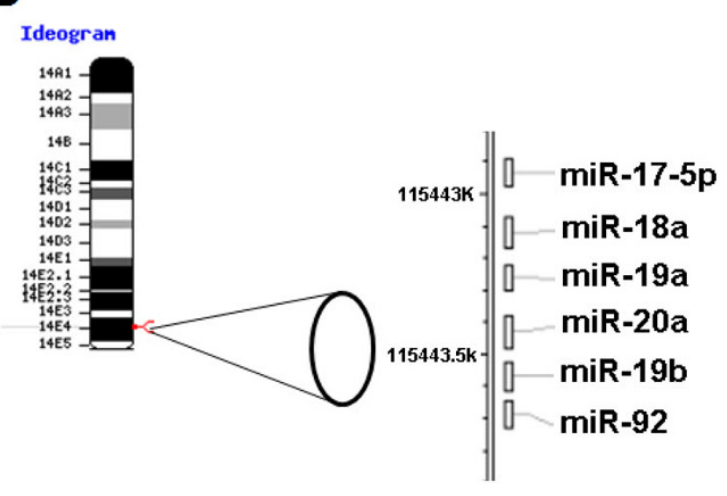

B

\begin{tabular}{|c|c|c|}
\hline \multirow{5}{*}{ 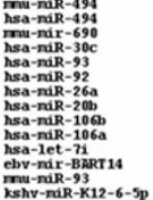 } & NAME & Mouse Th1/Th2 \\
\hline & hsa-miR-142-3p & 3.86 \\
\hline & hsa-miR-92 & 3.66 \\
\hline & hsa-miR-20a & 3.66 \\
\hline & hsa-miR-106a & 3.642 \\
\hline \multirow{3}{*}{$\begin{array}{l}\text { hsa-nir-560 } \\
\text { hsa-niR-27a } \\
\text { hsa-niR-20b } \\
\text { hsa-niR-19b } \\
\text { ma-niR-106a } \\
\text { hsa-niR-98 } \\
\text { hsa-niR-221 }\end{array}$} & mmu-miR-106a & 3.561 \\
\hline & hsa-miR-30c & 3.551 \\
\hline & hsa-miR-19a & 3.492 \\
\hline \multirow{5}{*}{ 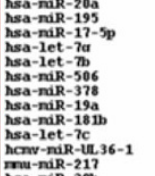 } & hsa-miR-20b & 3.451 \\
\hline & hsa-miR-142-3p & 3.355 \\
\hline & hsa-let-7g & 3.173 \\
\hline & hsa-miR-19b & 3.134 \\
\hline & hsa-miR-17-5p & 3.06 \\
\hline \multirow{3}{*}{ 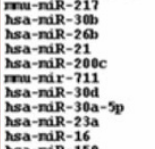 } & hsa-miR-195 & 3.048 \\
\hline & mmu-miR-93 & 2.917 \\
\hline & hsa-miR-26a & 2.882 \\
\hline \multirow{3}{*}{ 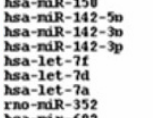 } & hsa-miR-93 & 2.87 \\
\hline & hsa-miR-20b & 2.864 \\
\hline & hsa-let-7i & 2.704 \\
\hline \multirow{5}{*}{ 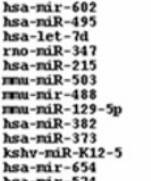 } & hsa-miR-21 & 2.566 \\
\hline & hsa-let-7f & 2.433 \\
\hline & hsa-let-7c & 2.408 \\
\hline & hsa-miR-106b & 2.369 \\
\hline & hsa-miR-98 & 2.35 \\
\hline
\end{tabular}

Figure 1 Microarray analysis demonstrates up-regulation of miR-17-92 in Th1 cells. (A), Intracellular IFN- $\gamma$ Vs. IL-4 expression of Th1 and Th2 cells induced from mouse CD4 ${ }^{+}$splenic T cells in vitro. (B), Differentially expressed miRs were analyzed by hierarchical clustering of the log2 value of Th1/Th2 pair of miR microarray signal. Red indicates up-regulation in Th1; green, up-regulation in Th2. (C), miRs were ranked by relative fold expression in Th1/Th2 cells. Arrows indicate members of the miR-17-92 cluster or paralog clusters. miRs with a relative expression of $>2.35$ fold in Th1 are shown. (B and C), hsa- and mmu- indicate human and mouse miR probes, respectively. Hsa-probes can hybridize with most mouse miR due to the high homology and mmu-signals are shown only when murine miR has unique sequence compared to its human counterpart. (D), Ideogram of mouse chromosome 14 showing the location and order of the miR-17-92 cluster (adapted from NCBI Blast). 
Th1 cells compared to Th2 cells. Since miR-17-92 clusters appear to be transcribed as single polycistronic transcripts (Fig. 1D), we expected that all the miRs from the miR-17-92 cluster would be consistently expressed at higher levels in Th1 cells than in Th2 cells, which was confirmed by RT-PCR analysis (Fig. 2A).

The miR-17-92 cluster has 2 paralog clusters: miR106a-363 and miR-106b-25. These paralog clusters target similar mRNAs as the miR-17-92 cluster due to high sequence homology [34]. To establish if these paralog miR clusters are also overexpressed in our Th1 vs. Th2 cells, we next performed RT-PCR for miRs in each of these clusters. Representative for these paralog clusters are miR-106a and miR106b (Fig. 2B). These data demonstrate that the paralog clusters of miRs were also up-regulated in Th1 cells over Th2.

Neutralization of endogenous IL-4 up-regulates miR-17-92 cluster miRs in T-cells

In order to identify factors that contribute to the differential expression of miR-17-92 cluster miRs between
Th1 and Th2 cells, we next sought to determine whether a prototypical type-2 inducing cytokine, IL-4, would affect miR-17-92 expression in CD4 ${ }^{+} \mathrm{T}$ cells. Neutralization of endogenous IL- 4 by specific $\mathrm{mAb}$ against IL-4 up-regulated miR-17-92 cluster miRs in $\mathrm{CD}^{+}{ }^{+} \mathrm{T}$ cells stimulated with IL- 2 without addition of Th1-inducing factors IL-12 or IFN- $\gamma$, by approximately $50 \%$ (Fig. 3A). The anti-IL-4 mAb also up-regulated miR-17-92 in Th2 culture conditions as well (data not shown). To determine whether there is an IL-4 dosedependent suppression of miR-17-92 cluster, we next treated $\mathrm{CD}^{+}{ }^{+} \mathrm{T}$ cells with increasing doses of IL-4 at 0 , 10,50 or $100 \mathrm{ng} / \mathrm{ml}$ and measured miR-17-5p expression by RT-PCR (Fig. 3B). miR-17-92 suppression was a dose-dependent phenomenon.

\section{Up-regulated miR-17-92 expression in STAT6 deficient T cells}

To further elucidate the effect of IL-4 signaling on miR17-92 cluster expression, we next cultured $\mathrm{CD}^{+}{ }^{+} \mathrm{T}$ cells under Th1 or Th2 skewing conditions from mice deficient

\section{A} miR-17-5p miR-18a miR-19a
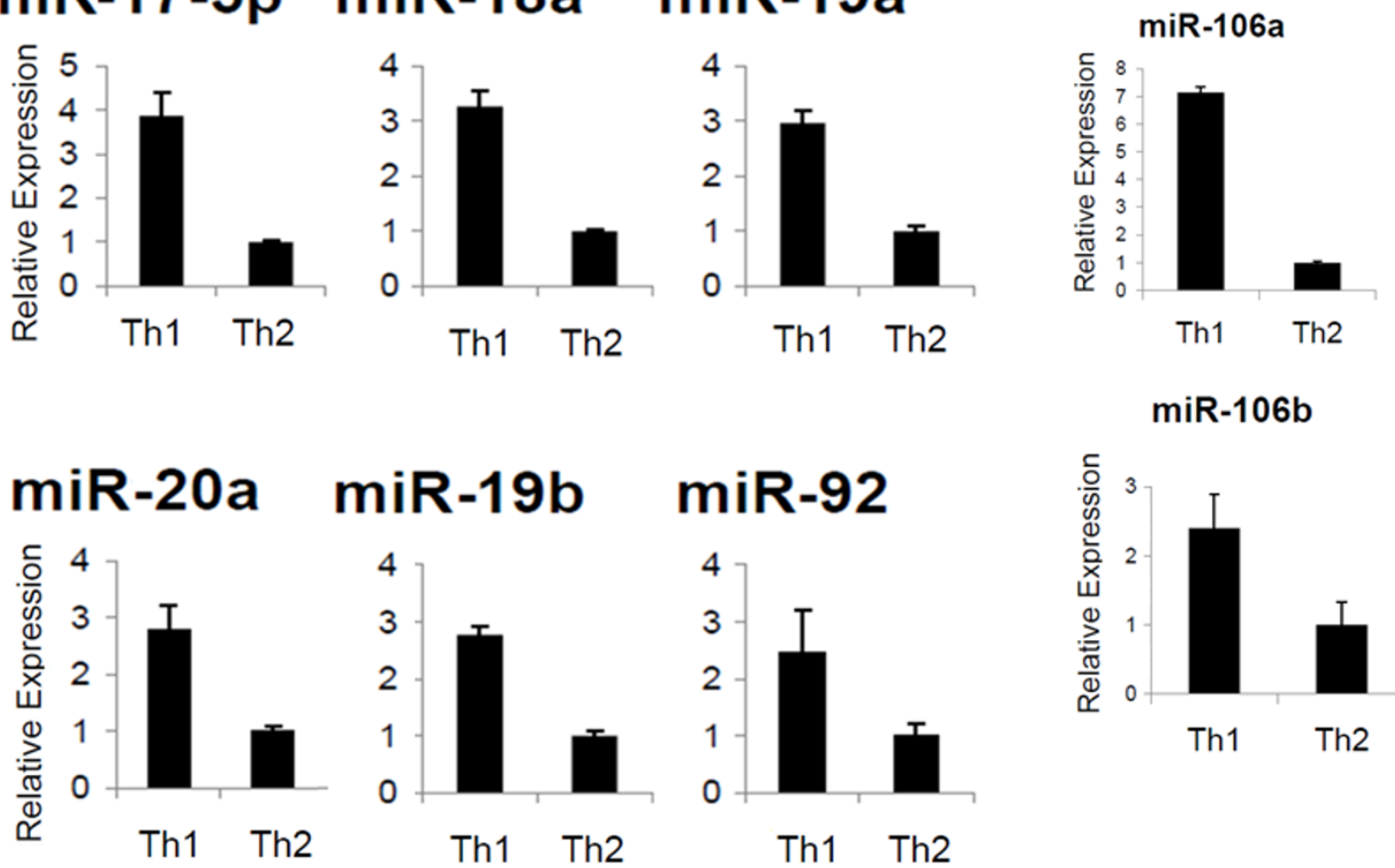

\section{B}

$\operatorname{miR}-106 b$

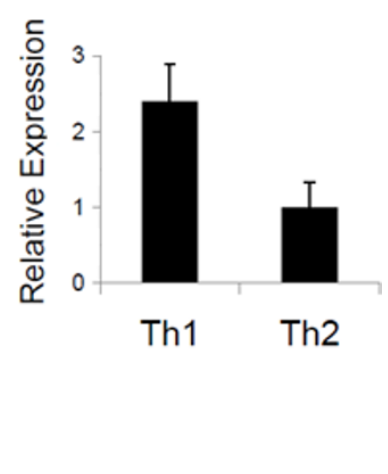

Figure 2 Enhanced expression of miRs from the miR-17-92 cluster in Th1 cells. Data represent relative expression of mature miRs in Th1 compared with Th2 cells. SNO202 was used as the internal control and $\triangle \triangle C_{T}$ method was used to examine expression relative to the Th2 cell value. Relative expression is shown for (A), miR-17-92 cluster members or (B), representative paralog cluster members, miR-106a and -106b. Error Bars indicate standard deviation of the triplicate samples. Each experiment was repeated at least 3 times. Up-regulation in Th1 vs. Th2 is significant in (A) with $p<.01$ for miR-92 and $p<.0001$ for all other miRs and in (B), with $p<.001$ for miR-106a and $p<.05$ for miR106b using the student $t$ test. 


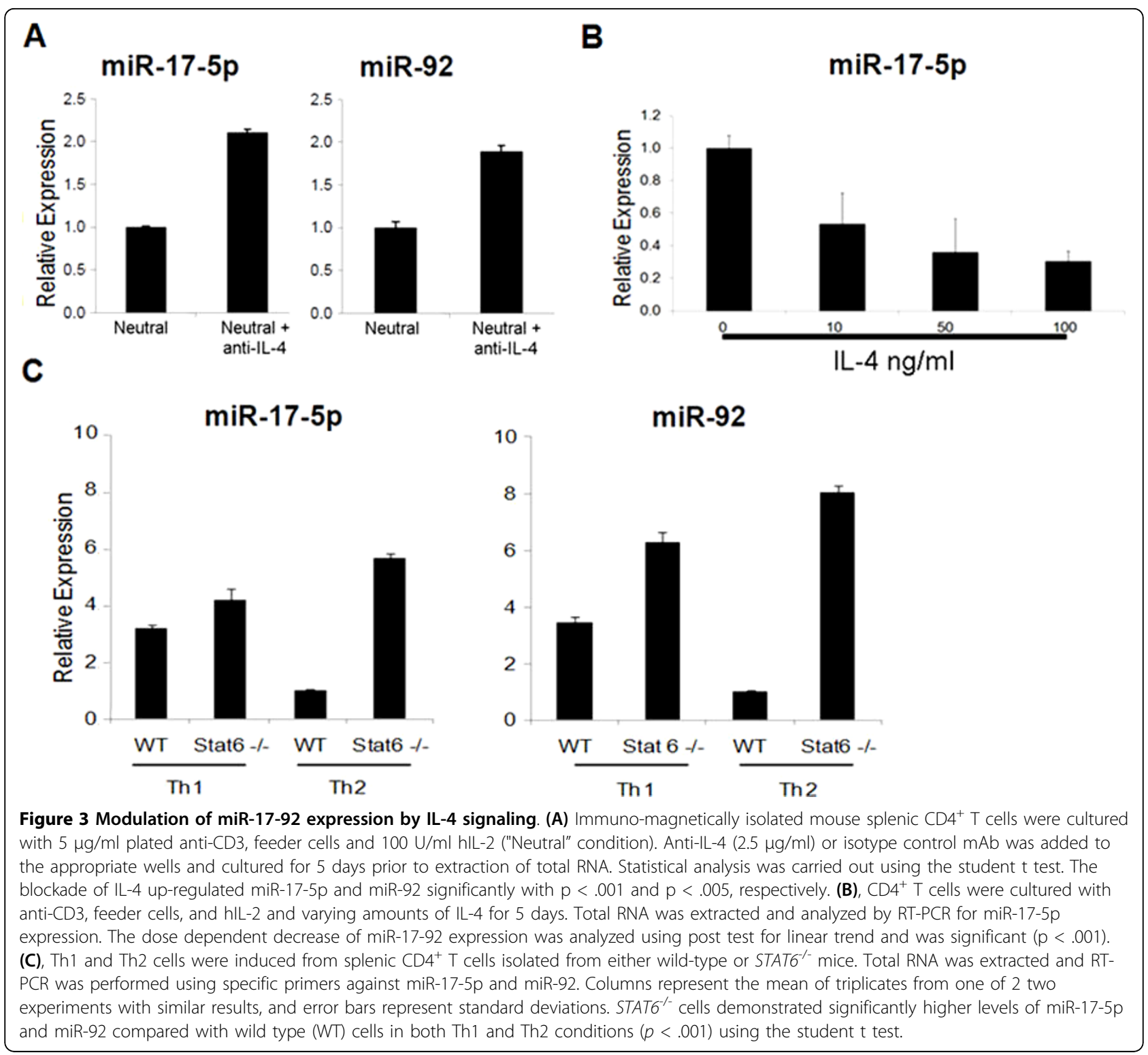

of the critical IL-4 signaling molecule, STAT6 $[4,35]$. Both Th1 and Th2 cultured cells induced from STAT6-deficient mice showed higher levels of miR-17-5p expression compared with corresponding WT Th cells, suggesting a novel critical role of IL-4R/STAT6-signaling in the down-regulation of miR-17 expression (Fig. 3C).

\section{Suppression of miR-17-92 may occur in cancer-bearing hosts}

These data led us to hypothesize that suppression of miR-17-92 would occur in cancer-bearing hosts where tumor-derived factors likely promote Th2-skewed immune responses and secretion of IL-4 [8]. Indeed, $\mathrm{CD}^{+}{ }^{+}$and $\mathrm{CD} 8^{+}$splenocytes (SPCs) derived from wild type C57BL/6 mice bearing B16 subcutaneous tumors expressed lower levels of miR-17-5p when compared with those derived from non-tumor bearing mice (Fig. $4 \mathrm{~A})$. Interestingly, the tumor bearing condition did not suppress miR-17-5p expression by $\mathrm{CD}^{+} \mathrm{T}$ cells in $S_{T A T 6^{-1-}}$ mice. Furthermore, $\mathrm{CD}^{+}{ }^{\mathrm{T}}$ cells in STAT6 ${ }^{-1-}$ mice demonstrated enhanced levels of miR-17-5p expression when these mice bore B16 tumors compared with non-tumor bearing mice. When wild type $\mathrm{CD} 4^{+}$ $\mathrm{T}$ cells were stimulated with anti-CD3 mAb in vitro for 24 hours, the $\mathrm{CD} 4^{+} \mathrm{T}$ cells from tumor-bearing mice produced lower levels of IFN $-\gamma$ when compared with ones from non-tumor bearing wild type mice (Fig. 4B). These data suggest that tumor-associated immunosuppression may involve the down-regulation of miR-17-92 through a STAT6 dependant pathway. 


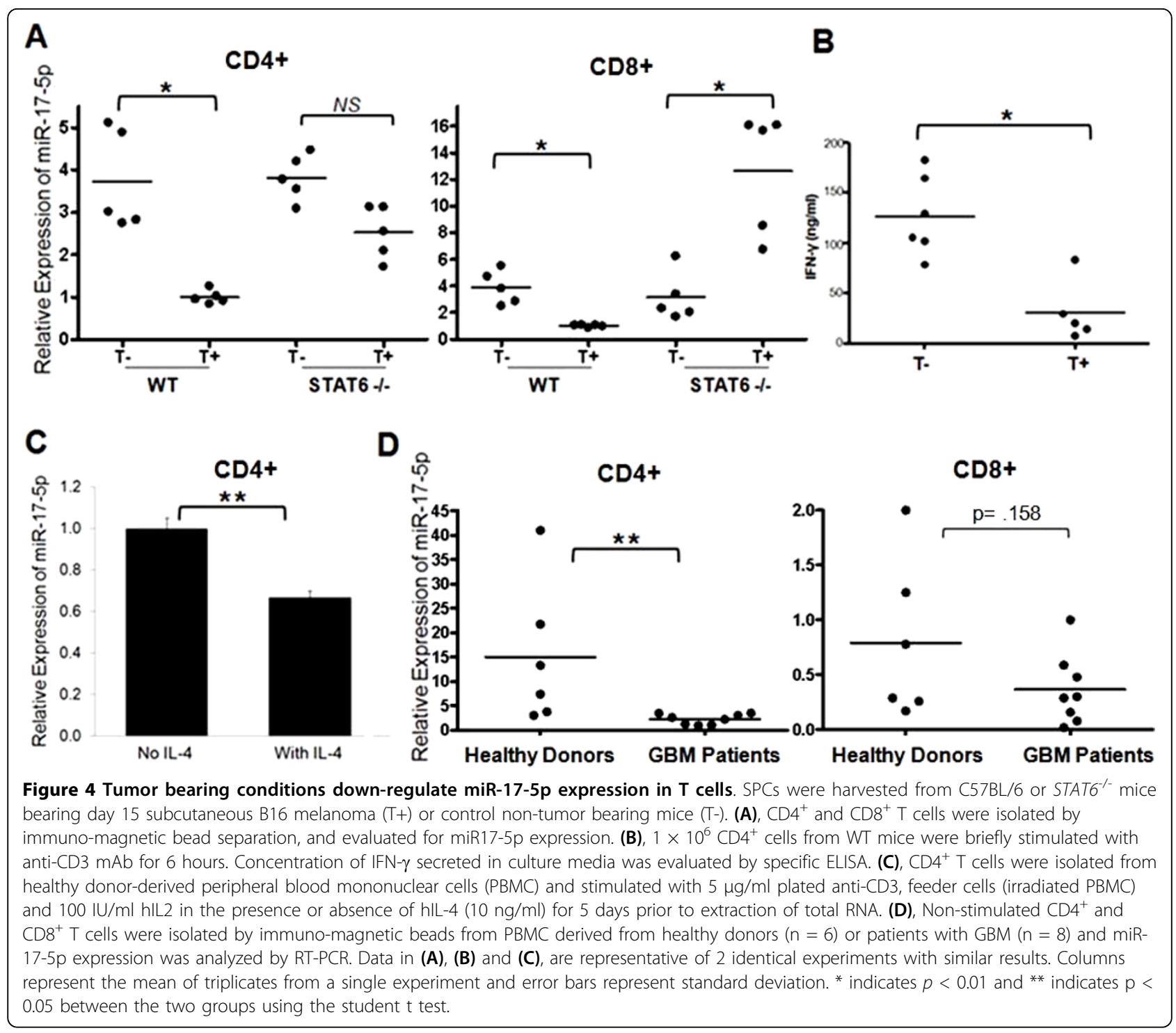

We next evaluated whether the observed IL-4mediated and tumor-induced suppression of miR-1792 are relevant in human $\mathrm{T}$ cells. When healthy donor-derived $\mathrm{CD}_{4}^{+} \mathrm{T}$ cells were stimulated with rhIL2, anti-CD3 and anti-CD28 mAbs, consistent with the mouse data, addition of rhIL-4 in the cultures suppressed expression of miR-17-5p (Fig. 4C). Moreover, $\mathrm{CD}^{+}{ }^{+} \mathrm{T}$ cells obtained from patients with GBM exhibited significantly decreased levels of miR-17-5p when compared with ones from healthy donors (Fig. 4D). Thus both IL-4 and GBM-bearing conditions suppress miR-17-5p expression in $\mathrm{CD}^{+}{ }^{+} \mathrm{T}$ cells. Although not statistically significant, $\mathrm{CD}^{+} \mathrm{T}$ cells demonstrated a trend towards decreased levels of miR-17-5p expression in GBM patients when compared with healthy donors (Fig. 4D).
T cells derived from miR-17-92 transgenic mice display enhanced type- 1 phenotype

The data discussed above strongly suggest GBM-associated factors and a type- 2 promoting cytokine (IL-4) down-regulate miR-17-92 in T cells. miR-17-92 is expected to play pivotal roles in $\mathrm{T}$ cell functions. We therefore sought to determine whether ectopic expression of miR-17-92 would promote the type- 1 phenotype of $\mathrm{T}$ cells. As detailed in Materials and Methods, we produced mice that overexpress miR-17-92 specifically in T cells (miR-17-92 TG/TG). We isolated CD4 ${ }^{+}$splenocytes from these mice and evaluated the expression of miR-17-5p (Fig. 5A). CD4 ${ }^{+}$cells from TG/TG mice displayed a greater than 15 fold increase in miR-17-p5 expression as compared with controls. These cells also expressed elevated levels of CD49d, which is a subunit 


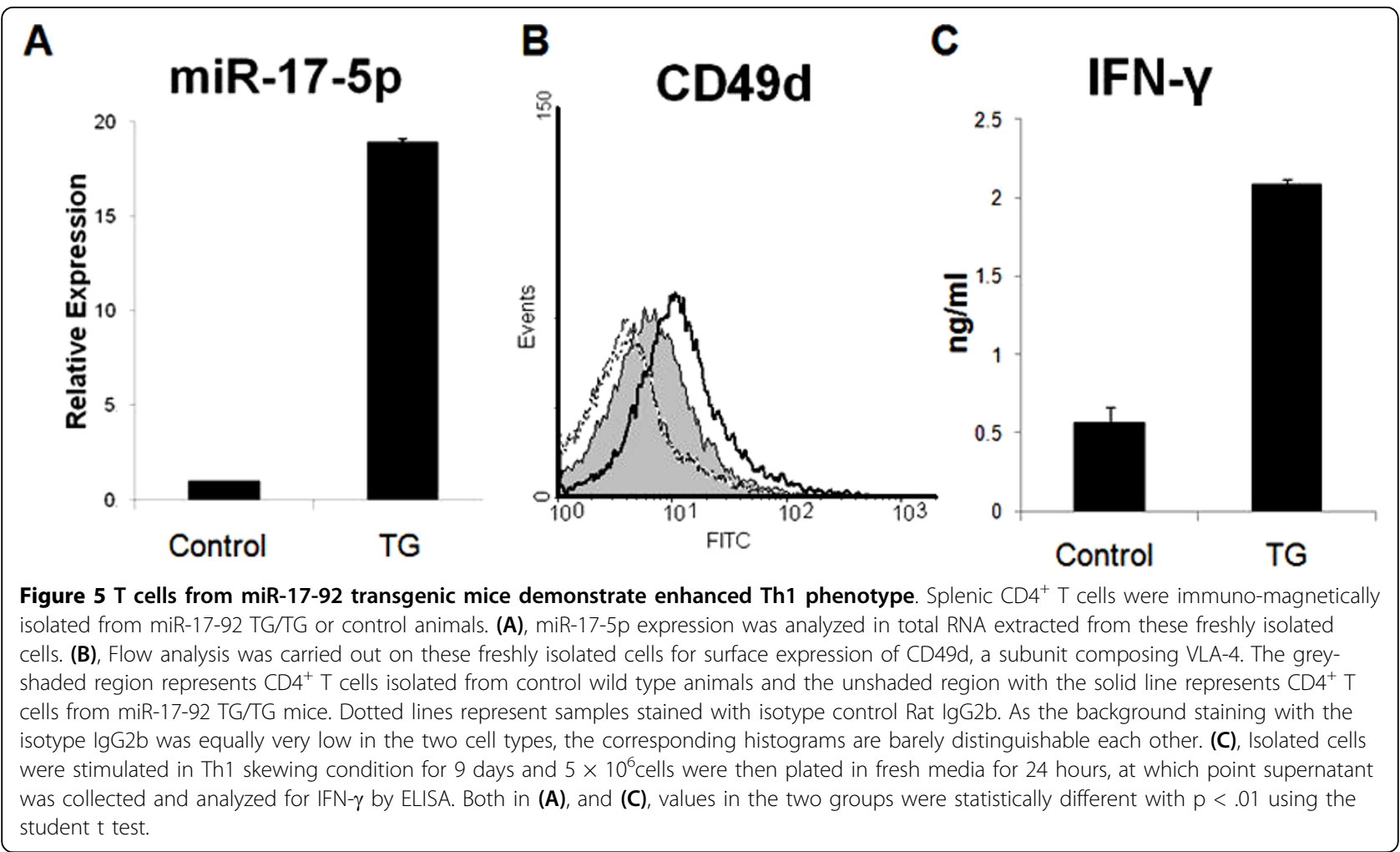

composing a type-1 $\mathrm{T}$ cell marker VLA-4 (Fig. 5B). Although CD49d (also known as $\alpha 4$-integrin) can form heterodimers with both $\beta 1$ (CD29) and $\beta 7$ integrins, $\alpha 4 \beta 7$ complexes were not expressed by either Th1 cells or Th2 cells, suggesting that CD49d is a suitable surrogate for VLA-4 expression levels [4-7]. miR-17-92-TG/ TG $\mathrm{CD}^{+}$cells also demonstrated enhanced ability to produce IFN- $\gamma$ upon stimulation (Fig. 5C). Similar data were obtained with $\mathrm{CD}^{+} \mathrm{T}$ cells isolated from these TG/TG mice (data not shown). These findings suggest that miR-17-92 promotes the type-1 phenotype in differentiating $\mathrm{T}$ cells.

\section{Ectopic expression of miR-17-92 promotes IL-2} production and resistance against activation-induced cell death (AICD) in Jurkat cells

miR-17-92 is expected to play pivotal roles in $\mathrm{T}$ cell survival as well as functions. To evaluate these aspects, we transduced Jurkat cells with lentiviral vectors encoding green fluorescence protein (GFP) and either the miR17-92-1 expression vector encoding miR-17 18 and 19a, or the 17-92-2 expression vector encoding miR 20,19b, and 92. The control vector encodes GFP, but not miRs. Transduced Jurkat cells were stimulated with PMA and ionomycin for overnight before the supernatants were assayed for IL-2 production by ELISA (Fig. 6A). Transduction of either miR-vector promoted IL-2 production in Jurkat cells.
AICD and chemotherapy-induced suppression of T cells represent major obstacles for efficient $\mathrm{T}$ cell-based cancer immunotherapy [36,37]. We next examined whether transfection of Jurkat cells with miR-17-92 confers $\mathrm{T}$ cells resistant to AICD. AICD was induced by cultivation of Jurkat cells in the presence of $10 \mu \mathrm{g} / \mathrm{ml}$ anti-CD3 mAb, which is hyper-stimulatory and used as a standard method to induce AICD [38]. As demonstrated in (Fig. 6B), the growth of control Jurkat cells was significantly suppressed by nearly $25 \%$ in the AICD inducing condition compared with the same cells with the regular (growth-promoting) dose of anti-CD3 mAb $(1 \mu \mathrm{g} / \mathrm{ml})$. In contrast, the growth of Jurkat cells transduced with either miR-17-92-1 or miR-17-92-2 was not significantly altered by the high dose $(10 \mu \mathrm{g} / \mathrm{ml})$ of antiCD3 mAb, suggesting that the miR-17-92 transfection confers $\mathrm{T}$ cells with substantial resistance against AICD. These findings point to a potential utility for miR-17-92 transfected $\mathrm{T}$ cells in cancer immunotherapy.

\section{Discussion}

Attaining effective tumor immunity is a major goal of modern biologic therapy, limited by the tumor microenvironment and profound regulatory mechanisms limiting $\mathrm{T}$ cell and NK cell effectors. Here we show that the type-2-skewing tumor microenvironment induces downregulation of miR-17-92 expression in T cells, thereby hampering anti-tumor $\mathrm{T}$ cell responses. It also suggests 

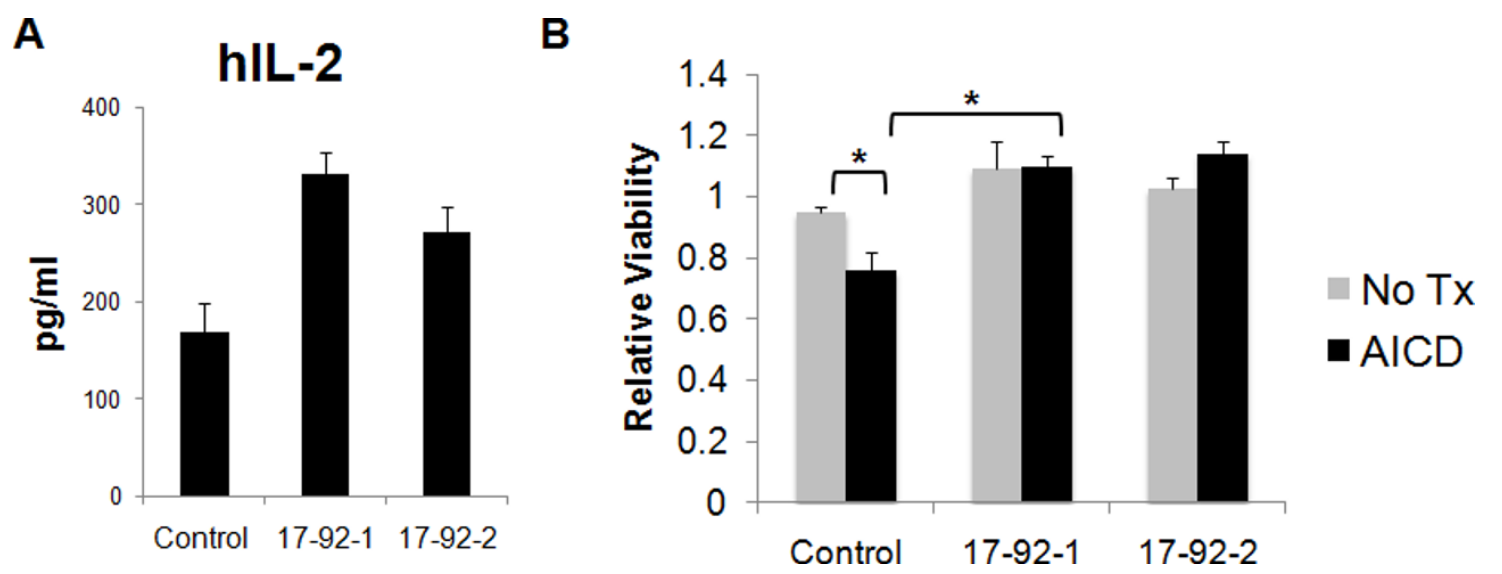

Figure 6 Ectopic expression of miR-17-92 cluster members in the human Jurkat T cell line confers increased IL-2 production and resistance to AICD. Jurkat cells were transduced by either one of the following pseudo typed lentivirus vectors: 1) control vector encoding GFP; 2) the 17-92-1 expression vector encoding miR-17 18 and 19a, or 3) the 17-92-2 expression vector encoding miR 20, 19b-1, and 92a-1. (A), Transduced Jurkat cells $\left(5 \times 10^{4}\right)$ in the triplicate wells were stimulated with PMA $(10 \mathrm{ng} / \mathrm{ml})$ and ionomycin $(500 \mathrm{nM})$ for overnight and supernatant was harvested and tested for the presence of IL-2 by specific ELISA. The figure shows mean values and standard deviations of the amount of IL-2 released from each group. Statistical analysis was carried out using the student t test, and significant $(p<.005)$ increase of IL-2 production was confirmed in both 17-92-1 and the 17-92-2 transduced groups compared with the control group. (B), Transduced Jurkat cells were treated with the AICD inducing condition $(10 \mu \mathrm{g} / \mathrm{ml}$ anti-CD3 mAb) or in complete media (No Tx) for 24 hrs. Then, the relative numbers of viable cells were evaluated by 4 hour WST-1 assays. The figure shows mean values and standard deviations of 8 wells/group each containing 5 $\times 10^{5}$ cells. For each group, the relative OD readings at $450 \mathrm{~nm}$ of AICD-treated cells compared with control Jurkat cells without AICD-treatment is indicated. * indicates $p<0.05$ between the two groups using student $t$ test.

that development of immunotherapy using miR-17-92transduced $\mathrm{T}$ cells is warranted based on our findings demonstrating that ectopic expression of miR-17-92 in $\mathrm{T}$ cells leads to improved type- 1 functions, including increased VLA-4 expression and IFN- $\gamma$ production.

Blockade of endogenous IL-4 by inhibitory mAb or disruption of STAT6 signaling was sufficient to up-regulate miR-17-92 in T cells (Fig 3). These findings suggest that STAT6 may negatively regulate miR-17-92 expression in T cells. Several transcription factors have been identified that regulate expression of this miR cluster, including the E2 transcription factor (E2F) family members [39,40], c-Myc [41], STAT3 [42], as well as the sonic hedgehog pathway $[43,44]$. How IL-4 and the STAT6 signaling pathway negatively influence miR-1792 expression at a molecular level remains to be elucidated. With regard to the effects of IL-4/STAT6 signaling on Th1 vs. Th2 functions, we have recently demonstrated that STAT6-/- Th2 cells exhibit Th1 phenotype with increased surface expression of VLA-4 [45]. These observations have led us to hypothesize that STAT6-regulated miR-17-92 may contribute to the promotion of type- $1 \mathrm{~T}$ cell functions.

Our findings indicate that the tumor-bearing host down-regulates miR-17-92 in T cells (Fig. 3 and 4). Interestingly, not only are $S T A T 6^{-1-} \mathrm{T}$ cells resistant to tumor-induced inhibition of miR-17-5p, but $\mathrm{CD}^{+} \mathrm{T}$ cells in tumor bearing $S T A T 6^{-1-}$ mice exhibited higher levels of miR-17-5p when compared with $\mathrm{CD} 8^{+} \mathrm{T}$ cells obtained from non-tumor bearing STAT6 ${ }^{-1-}$ mice. In addition to IL-4, other tumor-derived factors are likely to be involved in these events. Further studies are warranted to elucidate the molecular mechanisms underlying the regulation of miR-17-92 in T cells, especially in the tumor microenvironment.

While tumor bearing mice demonstrated decreased levels of miR-17-92 in both $\mathrm{CD}^{+}$and $\mathrm{CD}^{+}$cells, human GBM patients exhibited a statistically significant decrease of miR-17-92 in CD $4^{+}$cells but not in $\mathrm{CD} 8^{+}$ cells (Fig. 4). However, there still appears to be a trend towards lower miR-17-92 expression in GBM patientderived $\mathrm{CD}^{+}$cells compared with those obtained from healthy donors. The lesser degree of miR-17-92 suppression in $\mathrm{CD}^{+}$cells compared with $\mathrm{CD}^{+}$cells in GBM patients is plausible based on our current understanding of $\mathrm{CD}^{+}$and $\mathrm{CD}^{+} \mathrm{T}$ cell biology. The type- 1 vs. type- 2 differentiation appears to be more distinct for $\mathrm{CD}^{+} \mathrm{T}$ cells than for $\mathrm{CD}^{+}$cells $[46,47]$, and this may also be the case for miR-17-92. Another speculation is that $\mathrm{CD}^{+} \mathrm{T}$ cells may be less sensitive to $\mathrm{IL}-4$ than $\mathrm{CD} 4^{+}$ $\mathrm{T}$ cells thereby exhibiting less repression of miR-17-92. Further studies with larger sample size are warranted.

Messages encoding proteins that are targeted by miR17-92 cluster miRs include: E2F1, E2F2, E2F3 [40,41], P21 [48], anti-angiogenic thrombospondin-1 and connective tissue growth factor [49], proapoptotic Bim, and phosphatase and tensin homolog (PTEN) [24]. These proteins are all involved in cell cycle regulation or 
apoptotic cell death, further supporting the importance of miR-17-92 cluster in T cell biology. In fact, Bim and PTEN are down-regulated in $\mathrm{T}$ cells overexpressing miR-17-92 [24]. Furthermore, TGF- $\beta$ receptor II (TGFBRII) is one of the established targets of miR-1792 [50]. We are currently evaluating whether miR-17-92 transgenic $\mathrm{T}$ cells show down-regulated TGFBRII and decreased sensitivity to TGF- $\beta$.

In agreement with others [24], our findings demonstrating increased IFN- $\gamma$ production from miR-17-92 TG/TG T cells compared with control cells suggest that miR-17-92 may actually promote the type-1 skewing of $\mathrm{T}$ cells (Fig. 5 and $6 \mathrm{C}$ ). As miR-17-92 targets hypoxiainducible factor (HIF) $-1 \alpha$ in lung cancer cells [51], enhanced miR-17-92 expression in activated $\mathrm{T}$ cells may promote the type- 1 function of $\mathrm{T}$ cells at least partially through down-regulation of HIF-1 $\alpha$. Although HIF-1 expression provides an important adaptation mechanism of cells to low oxygen tension [52,53], it does not appear to be critical for survival of $\mathrm{T}$ cells, unlike its apparent role in macrophages [54]. T cells do not depend on HIF- $1 \alpha$ for survival to the same degree as macrophages since activated $\mathrm{T}$ cells produce ATP by both glycolysis and oxidative phosphorylation [55]. Rather, HIF-1 $\alpha$ in T cells appears to play an anti-inflammatory and tissueprotecting role by negatively regulating $\mathrm{T}$ cell functions $[52,56,57]$. Indeed, T cell-targeted disruption of HIF-1 $\alpha$ leads to increased IFN- $\gamma$ secretion and/or improved effector functions [58-61]. Although available data on gene expression profiles in Th1 and Th2 cells do not suggest differential expression of HIF- $1 \alpha$ mRNA between these cell populations [62], as is often the case in miR-mediated gene expression regulation, miR-17-92 may still regulate HIF- $1 \alpha$ protein expression at posttranscriptional levels. These data collectively suggest that miR-17-92 expression in activated $\mathrm{T}$ cells may promote the type- 1 function of $\mathrm{T}$ cells at least partially through down-regulation of HIF- $1 \alpha$.

The human Jurkat $\mathrm{T}$ cell line with ecotopic expression of miR-17-92 cluster members demonstrate increased IL-2 production and improved viability following treatment with the AICD condition (Fig. 6). The Jurkat cell line was established from the peripheral blood of a $\mathrm{T}$ cell leukemia patient in the 1970s. This cell line is often used to recapitulate what would happen in humans $\mathrm{T}$ cells as the line retains many $\mathrm{T}$ cell properties, such as CD4, a T cell receptor, and ability to produce IL-2 [63]. For these reasons, we chose to use Jurkat cells in our experiments. We recognize, on the other hand, that this cell line has pitfalls since this is a tumor cell line with enhanced survival compared to normal $\mathrm{T}$ cells due to their intrinsic biology. Thus, continued work with human $\mathrm{T}$ cells is clearly warranted.
miRs in the miR-17-92 clusters are amplified in various tumor types including B cell lymphoma and lung cancer, and promote proliferation and confer anti-apoptotic function in tumors, thereby promoting tumor-progression and functioning as oncogenes [27-31]. However, miR-17-92 by itself may not be responsible for oncogenesis as transgenic mice with miR-17-92 overexpressed in lymphocytes develop lymphoproliferative disorder and autoimmunity but not cancer [24]. miR-17-92 may cooperate with other oncogenes to promote the oncogenic process. Transgenic mice overexpressing both miR-17-92 and c-Myc in lymphocytes develop early onset lymphomagenesis disorders [27]. On the other hand, knockout studies of the miR-1792 cluster in mice have demonstrated the importance of this cluster in mammalian biology. While knockout of the miR-17-92 cluster results in immediate post-natal death of all progeny, knockout of either or both the miR106a or miR-106b clusters are viable without an apparent phenotype [64]. However knock out of the miR-17-92 cluster together with miR-106a or 106b cluster results in embryonic lethality [25].

During lymphocyte development, miR-17-92 miRs are highly expressed in progenitor cells, with the expression level decreasing 2- to 3-fold following maturation [24]. In addition, we have evaluated relative expression of miR17-92 in a variety of Th cells as well as naïve $\mathrm{CD} 4^{+}$cells. Naïve $\mathrm{CD}^{+}{ }^{+}$cells express miR-17-92 at the highest level among the cell populations examined. Albeit lower than that in naïve $\mathrm{CD} 4^{+}$cells, Th1 cells express miR-17-92 at higher levels than $\mathrm{T}$ neutral (anti-CD3, feeder cells and IL-2) and Th17 cells, and Th2 cells consistently exhibit the lowest levels of miR-17-92 among the populations tested (data not shown). More studies are warranted on the specific role of miR-17-92 during differentiation.

These studies reviewed above provide us with critical insights as to what has to be expected if we develop therapeutic strategies by modulating miR-17-92 expression. One major barrier for successful $\mathrm{T}$ cell-based cancer immunotherapy is the low persistence of tumor antigen (TA)-specific T cells in tumor-bearing hosts $[65,66]$. It seems promising to generate genetically modified TA-specific T cells ex vivo that are resistant to tumor-mediated immune suppression and mediate robust and long-lived anti-tumor responses. miR-17-92 cluster has the potential to confer resistance to tumor-derived immunosuppressive factors and to improve type- 1 reactivity. Further characterization of the role of miR-17-92 cluster in tumor antigen (TA)-specific CTLs is clearly warranted and may provide us with ability to develop novel immunotherapy strategies with genetically engineered $T$ cells. Additionally, identification of diminished miR-17-92 expression in the peripheral blood may emerge as an important biomarker in patients with malignancy. 


\section{Abbreviations}

miR: microRNA; VLA-4: very late antigen-4; AICD: apoptosis induced cell death; CNS: central nervous system; GBM: glioblastoma multiforme; ICAM-1: intracellular cell adhesion molecule-1; STAT6: signal transducers and activators of transcription-6; PMA: phorbol myristate acetate; SPC: splenocyte.

\section{Acknowledgements}

This study was carried out with Grant Support from: the National Institutes of Health [1R01NS055140 to H.O., 2P01 NS40923 to H.O., 1P01CA132714 to HO and P01 CA 101944-01A2 to MTL] and Musella Foundation to HO. We thank Lisa Baily, Sebnem Unlu, Kayla McKaveney, Sandra Le Quellec, Stephanie Chen, and Munia Islam for their technical assistance.

\section{Author details}

'Department of Dermatology, University of Pittsburgh School of Medicine, 200 Lothrop Street, Pittsburgh, PA, 15213, USA. '2Department of Immunology, University of Pittsburgh School of Medicine, 200 Lothrop Street, Pittsburgh, PA, 15213, USA. ${ }^{3}$ Department of Neurological Surgery, University of Pittsburgh School of Medicine, 200 Lothrop Street, Pittsburgh, PA, 15213, USA. ${ }^{4}$ Department of Surgery, University of Pittsburgh School of Medicine, 200 Lothrop Street, Pittsburgh, PA, 15213, USA. ${ }^{5}$ Brain Tumor Program, University of Pittsburgh Cancer Institute, G12a Hillman Cancer Center, 5117 Centre Ave, Pittsburgh, PA, 15213, USA. ${ }^{6}$ Department of Infectious Diseases and Microbiology, University of Pittsburgh Graduate School of Public Health, A419 Crabtree Hall, Pittsburgh, PA 15261, USA. "National Institutes of Health, Department of Transfusion Medicine, Building 10, Room 1C711, Clinical Center, Bethesda, MD 20892, USA.

\section{Authors' contributions}

GK participated in the conception of the study, experimental design, performed in vivo and in vitro assays, and was one of the two primary writers of the paper. KS was involved in the conception of the study, further designing of the experiments, and took a primary role in culturing the differentiated T cells. AH performed studies using Jurkat cells. MF participated in experimental design, troubleshooting, editing the manuscript and statistical analysis. RU assisted in microRNA array and expression studies and analysis. HM helped with the ELISA and technical editing of the manuscript. TAR, JM and MTL participated in the design of experiments and interpretation of data. EW and FMM performed the miR microarray and assisted with analysis. $\mathrm{HO}$ conceived the study, mentored primary authors, was one of the two primary writers of the paper, and heavily participated in experimental design and data analysis. All authors read and approved the final manuscript.

\section{Competing interests}

The authors declare that they have no competing interests.

Received: 25 November 2009

Accepted: 18 February 2010 Published: 18 February 2010

\section{References}

1. Nishimura F, Dusak JE, Eguchi J, Zhu X, Gambotto A, Storkus WJ, Okada H: Adoptive transfer of Type 1 CTL mediates effective anti-central nervous system tumor response: critical roles of IFN-inducible protein-10. Cancer Res 2006, 66:4478-4487.

2. Fujita M, Zhu X, Sasaki K, Ueda R, Low KL, Pollack IF, Okada H: Inhibition of STAT3 promotes the efficacy of adoptive transfer therapy using type-1 CTLs by modulation of the immunological microenvironment in a murine intracranial glioma. J Immunol 2008, 180:2089-2098.

3. Fujita M, Zhu X, Ueda R, Sasaki K, Kohanbash G, Kastenhuber ER, McDonald HA, Gibson GA, Watkins SC, Muthuswamy R, et al: Effective Immunotherapy against Murine Gliomas Using Type 1 Polarizing Dendritic Cells-Significant Roles of CXCL10. Cancer Res 2009, 69:1587-1595.

4. Sasaki K, Zhao X, Pardee AD, Ueda R, Fujita M, Sehra S, Kaplan MH, Kane LP, Okada H, Storkus WJ: Stat6 signaling suppresses VLA-4 expression by CD8+ T cells and limits their ability to infiltrate tumor lesions in vivo. The Journal of Immunology 2008, 181:104-108.

5. Sasaki K, Pardee AD, Okada H, Storkus WJ: IL-4 inhibits VLA-4 expression on Tc1 cells resulting in poor tumor infiltration and reduced therapy benefit. Eur J Immunol 2008, 38:2865-2873.
6. Zhu X, Nishimura F, Sasaki K, Fujita M, Dusak JE, Eguchi J, Fellows-Mayle W, Storkus WJ, Walker PR, Salazar AM, Okada H: Toll like receptor-3 ligand poly-ICLC promotes the efficacy of peripheral vaccinations with tumor antigen-derived peptide epitopes in murine CNS tumor models. J Trans/ Med 2007, 5:10.

7. Sasaki K, Zhu X, Vasquez C, Nishimura F, Dusak JE, Huang J, Fujita M, Wesa A, Potter DM, Walker PR, et al: Preferential expression of very late antigen-4 on type 1 CTL cells plays a critical role in trafficking into central nervous system tumors. Cancer Res 2007, 67:6451-6458.

8. Roussel E, Gingras MC, Grimm EA, Bruner JM, Moser RP: Predominance of a type 2 intratumoural immune response in fresh tumour-infiltrating lymphocytes from human gliomas. Clin Exp Immunol 1996, 105:344-352.

9. Weller $\mathrm{M}$, Fontana $\mathrm{A}$ : The failure of current immunotherapy for malignant glioma. Tumor-derived TGF-beta, T-cell apoptosis, and the immune privilege of the brain. Brain Res 1995, 21:128-151.

10. Nitta T, Hishii M, Sato K, Okumura K: Selective expression of interleukin-10 gene within glioblastoma multiforme. Brain Res 1994, 649:122-128.

11. Jarnicki AG, Lysaght J, Todryk S, Mills KHG: Suppression of Antitumor Immunity by IL-10 and TGF-beta-Producing T Cells Infiltrating the Growing Tumor: Influence of Tumor Environment on the Induction of CD4+ and CD8+ Regulatory T Cells. J Immunol 2006, 177:896-904.

12. Prokopchuk O, Liu Y, Henne-Bruns D, Kornmann M: Interleukin-4 enhances proliferation of human pancreatic cancer cells: evidence for autocrine and paracrine actions. Br J Cancer 2005, 92:921-928.

13. Seo N, Hayakawa S, Takigawa M, Tokura Y: Interleukin-10 expressed at early tumour sites induces subsequent generation of $\mathrm{CD}^{+} \mathrm{T}$-regulatory cells and systemic collapse of antitumour immunity. Immunology 2001, 103:449-457.

14. Hammond SM: RNAi, microRNAs, and human disease. Cancer Chemother Pharmacol 2006, 58(Suppl 1):563-68.

15. Elmen J, Lindow $M$, Schutz $S$, Lawrence $M$, Petri $A$, Obad $S$, Lindholm $M$ Hedtjarn M, Hansen HF, Berger $U$, et al: LNA-mediated microRNA silencing in non-human primates. Nature 2008, 452:896-899.

16. Cheng AM, Byrom MW, Shelton J, Ford LP: Antisense inhibition of human miRNAs and indications for an involvement of miRNA in cell growth and apoptosis. Nucleic Acids Res 2005, 33:1290-1297.

17. Xu P, Guo M, Hay BA: MicroRNAs and the regulation of cell death. Trends Genet 2004, 20:617-624.

18. Karp $X, A m b r o s ~ V:$ Developmental biology. Encountering microRNAs in cell fate signaling. Science 2005, 310:1288-1289.

19. Chen CZ, Li L, Lodish HF, Bartel DP: MicroRNAs modulate hematopoietic lineage differentiation. Science 2004, 303:83-86.

20. Poy MN, Eliasson L, Krutzfeldt J, Kuwajima S, Ma X, Macdonald PE, Pfeffer S, Tuschl T, Rajewsky N, Rorsman P, Stoffel M: A pancreatic islet-specific microRNA regulates insulin secretion. Nature 2004, 432:226-230.

21. Thai TH, Calado DP, Casola S, Ansel KM, Xiao C, Xue Y, Murphy A, Frendewey D, Valenzuela $D$, Kutok $J$, et al: Regulation of the germinal center response by microRNA-155. Science 2007, 316:604-608.

22. O'Connell RM, Taganov KD, Boldin MP, Cheng G, Baltimore D: MicroRNA155 is induced during the macrophage inflammatory response. Proc Natl Acad Sci USA 2007, 104:1604-1609.

23. Ueda R, Kohanbash G, Sasaki K, Fujita M, Zhu X, Kastenhuber ER, McDonald HA, Potter DM, Hamilton RL, Lotze MT, et al: Dicer-regulated microRNAs 222 and 339 promote resistance of cancer cells to cytotoxic T-lymphocytes by down-regulation of ICAM-1. Proc Natl Acad Sci USA 2009, 106:10746-10751.

24. Xiao C, Srinivasan L, Calado DP, Patterson HC, Zhang B, Wang J, Henderson JM, Kutok JL, Rajewsky K: Lymphoproliferative disease and autoimmunity in mice with increased miR-17-92 expression in lymphocytes. Nat Immunol 2008, 9:405-414.

25. Xiao C, Rajewsky K: MicroRNA control in the immune system: basic principles. Cell 2009, 136:26-36.

26. Tanzer A, Stadler PF: Molecular Evolution of a MicroRNA Cluster. Journal of Molecular Biology 2004, 339:327-335.

27. He L, Thomson JM, Hemann MT, Hernando-Monge E, Mu D, Goodson S, Powers S, Cordon-Cardo C, Lowe SW, Hannon GJ, Hammond SM: A microRNA polycistron as a potential human oncogene. Nature 2005, 435:828-833.

28. Hayashita Y, Osada H, Tatematsu Y, Yamada H, Yanagisawa K, Tomida S, Yatabe Y, Kawahara K, Sekido Y, Takahashi T: A Polycistronic MicroRNA 
Cluster, miR-17-92, Is Overexpressed in Human Lung Cancers and Enhances Cell Proliferation. Cancer Res 2005, 65:9628-9632.

29. Matsubara H, Takeuchi T, Nishikawa E, Yanagisawa K, Hayashita Y, Ebi H, Yamada H, Suzuki M, Nagino M, Nimura Y, et al: Apoptosis induction by antisense oligonucleotides against miR-17-5p and miR-20a in lung cancers overexpressing miR-17-92. Oncogene 2007, 26:6099-6105.

30. Lawrie CH: MicroRNA expression in lymphoma. Expert Opin Biol Ther 2007, 7:1363-1374

31. Rinaldi A, Poretti G, Kwee I, Zucca E, Catapano CV, Tibiletti MG, Bertoni F: Concomitant MYC and microRNA cluster miR-17-92 (C13orf25) amplification in human mantle cell lymphoma. Leuk Lymphoma 2007 48:410-412.

32. Ren J, Jin P, Wang E, Marincola F, Stroncek D: MicroRNA and gene expression patterns in the differentiation of human embryonic stem cells. Journal of Translational Medicine 2009, 7:20.

33. Livak KJ, Schmittgen TD: Analysis of relative gene expression data using real-time quantitative PCR and the 2(-Delta Delta C(T)) Method. Methods 2001, 25:402-408.

34. Mendell JT: miRiad roles for the miR-17-92 cluster in development and disease. Cell 2008, 133:217-222

35. Eguchi J, Hiroishi K, Ishii S, Baba T, Matsumura T, Hiraide A, Okada H, Imawari M: Interleukin-4 gene transduced tumor cells promote a potent tumor-specific Th1-type response in cooperation with interferon-alpha transduction. Gene Ther 2005, 12:733-741.

36. Kennedy R, Celis E: Multiple roles for CD4+ T cells in anti-tumor immune responses. Immunological Reviews 2008, 222:129-144.

37. Brenner D, Krammer PH, Arnold Ri: Concepts of activated T cell death. Critical Reviews in Oncology/Hematology 2008, 66:52-64.

38. Jiang T, Han Z, Chen S, Wu C, Tang Y, Qian C, Chen Y, Zhou Y, Zhu Y, Gu M, et al: Resistance to activation-induced cell death and elevated FLIP(L) expression of CD4+ T cells in a polyl:C-induced primary biliary cirrhosis mouse model. Clin Exp Med 2009.

39. Woods K, Thomson JM, Hammond SM: Direct Regulation of an Oncogenic Micro-RNA Cluster by E2F Transcription Factors. J Biol Chem 2007, 282:2130-2134

40. Sylvestre Y, De Guire V, Querido E, Mukhopadhyay UK, Bourdeau V, Major F, Ferbeyre G, Chartrand P: An E2F/miR-20a Autoregulatory Feedback Loop. J Biol Chem 2007, 282:2135-2143.

41. O'Donnell KA, Wentzel EA, Zeller Kl, Dang CV, Mendell JT: c-Myc-regulated microRNAs modulate E2F1 expression. Nature 2005, 435:839-843.

42. Brock M, Trenkmann M, Gay RE, Michel BA, Gay S, Fischler M, Ulrich S, Speich R, Huber LC: Interleukin-6 modulates the expression of the bone morphogenic protein receptor type II through a novel STAT3-microRNA cluster 17/92 pathway. Circ Res 2009, 104:1184-1191.

43. Northcott PA, Fernandez LA, Hagan JP, Ellison DW, Grajkowska W, Gillespie Y, Grundy R, Van Meter T, Rutka JT, Croce CM, et al: The miR-17/ 92 polycistron is up-regulated in sonic hedgehog-driven medulloblastomas and induced by $\mathrm{N}$-myc in sonic hedgehog-treated cerebellar neural precursors. Cancer Res 2009, 69:3249-3255.

44. Uziel T, Karginov FV, Xie S, Parker JS, Wang YD, Gajjar A, He L, Ellison D, Gilbertson RJ, Hannon G, Roussel MF: The miR-17 92 cluster collaborates with the Sonic Hedgehog pathway in medulloblastoma. Proc Natl Acad Sci USA 2009, 106:2812-2817.

45. Sasaki K, Pardee AD, Qu Y, Zhao X, Ueda R, Kohanbash G, Bailey LM, Okada H, Muthuswamy R, Kalinski P, et al: IL-4 Suppresses Very Late Antigen-4 Expression Which is Required for Therapeutic Th1 T-cell Trafficking Into Tumors. Journal of Immunotherapy 2009, 32:793-802.

46. Ehi $\mathrm{K}$, Ishigami $\mathrm{S}$, Masamoto I, Uenosono $\mathrm{Y}$, Natsugoe $\mathrm{S}$, Arigami T, Arima $\mathrm{H}$, Kijima Y, Yoshinaka H, Yanagita S, et al: Analysis of T-helper type 1 and 2 cells and T-cytotoxic type 1 and 2 cells of sentinel lymph nodes in breast cancer. Oncol Rep 2008, 19:601-607.

47. Tatsumi T, Herrem CJ, Olson WC, Finke JH, Bukowski RM, Kinch MS, Ranieri E, Storkus WJ: Disease stage variation in CD4+ and CD8+ T-cell reactivity to the receptor tyrosine kinase $\mathrm{EphA} 2$ in patients with renal cell carcinoma. Cancer Res 2003, 63:4481-4489.

48. Inomata M, Tagawa H, Guo YM, Kameoka Y, Takahashi N, Sawada K: MicroRNA-17-92 down-regulates expression of distinct targets in different B-cell lymphoma subtypes. Blood 2009, 113:396-402.

49. Dews M, Homayouni A, Yu D, Murphy D, Sevignani C, Wentzel E, Furth EE, Lee WM, Enders GH, Mendell JT, Thomas-Tikhonenko A: Augmentation of tumor angiogenesis by a Myc-activated microRNA cluster. Nat Genet 2006, 38:1060-1065.

50. Volinia S, Calin GA, Liu C-G, Ambs S, Cimmino A, Petrocca F, Visone R, Iorio $M$, Roldo $C$, Ferracin $M$, et al: A microRNA expression signature of human solid tumors defines cancer gene targets. Proc Natl Acad Sci USA 2006, 103:2257-2261

51. Taguchi A, Yanagisawa K, Tanaka M, Cao K, Matsuyama Y, Goto H, Takahashi T: Identification of hypoxia-inducible factor-1 alpha as a novel target for miR-17-92 microRNA cluster. Cancer Res 2008, 68:5540-5545.

52. Sitkovsky M, Lukashev D: Regulation of immune cells by local-tissue oxygen tension: HIF1 alpha and adenosine receptors. Nat Rev Immunol 2005, 5:712-721.

53. Semenza GL: Hypoxia-inducible factor 1: master regulator of $\mathrm{O} 2$ homeostasis. Current Opinion in Genetics \& Development 1998, 8:588-594

54. Cramer T, Yamanishi Y, Clausen BE, Förster I, Pawlinski R, Mackman N, Haase VH, Jaenisch R, Corr M, Nizet V, et al: HIF-1 $\alpha$ Is Essential for Myeloid Cell-Mediated Inflammation. 2003, 112:645-657.

55. Brand K, Hermfisse U: Aerobic glycolysis by proliferating cells: a protective strategy against reactive oxygen species. FASEB J 1997, 11:388-395.

56. Neumann AK, Yang J, Biju MP, Joseph SK, Johnson RS, Haase VH, Freedman BD, Turka LA: Hypoxia inducible factor $1 \alpha$ regulates $T$ cell receptor signal transduction. Proceedings of the National Academy of Sciences of the United States of America 2005, 102:17071-17076.

57. Eltzschig HK, Thompson LF, Karhausen J, Cotta RJ, Ibla JC, Robson SC, Colgan SP: Endogenous adenosine produced during hypoxia attenuates neutrophil accumulation: coordination by extracellular nucleotide metabolism. Blood 2004, 104:3986-3992.

58. Kojima H, Gu H, Nomura S, Caldwell CC, Kobata T, Carmeliet P, Semenza GL, Sitkovsky MV: Abnormal B lymphocyte development and autoimmunity in hypoxia-inducible factor $1 \alpha$-deficient chimeric mice. Proceedings of the National Academy of Sciences of the United States of America 2002, 99:2170-2174.

59. Lukashev D, Klebanov B, Kojima H, Grinberg A, Ohta A, Berenfeld L, Wenger RH, Ohta A, Sitkovsky M: Cutting Edge: Hypoxia-Inducible Factor 1 alpha\} and Its Activation-Inducible Short Isoform I.1 Negatively Regulate Functions of CD4+ and CD8+ T Lymphocytes. J Immunol 2006, 177:4962-4965.

60. Guo J, Lu W, Shimoda LA, Semenza GL, Georas SN: Enhanced interferongamma gene expression in $T$ Cells and reduced ovalbumin-dependent lung eosinophilia in hypoxia-inducible factor-1-alpha-deficient mice. Int Arch Allergy Immunol 2009, 149:98-102.

61. Thiel M, Caldwell CC, Kreth S, Kuboki S, Chen P, Smith P, Ohta A, Lentsch AB, Lukashev D, Sitkovsky MV: Targeted deletion of HIF-1alpha gene in T cells prevents their inhibition in hypoxic inflamed tissues and improves septic mice survival. PLoS One 2007, 2:e853.

62. Nagai S, Hashimoto S, Yamashita T, Toyoda N, Satoh T, Suzuki T, Matsushima K: Comprehensive gene expression profile of human activated T(h)1- and T(h)2-polarized cells. Int Immunol 2001, 13:367-376.

63. Abraham RT, Weiss A: Jurkat T cells and development of the T-cell receptor signalling paradigm. Nat Rev Immunol 2004, 4:301-308.

64. Ventura A, Young AG, Winslow MM, Lintault L, Meissner A, Erkeland SJ, Newman J, Bronson RT, Crowley D, Stone JR, et al: Targeted deletion reveals essential and overlapping functions of the miR-17 through 92 family of miRNA clusters. Cell 2008, 132:875-886.

65. Morgan RA, Dudley ME, Wunderlich JR, Hughes MS, Yang JC, Sherry RM Royal RE, Topalian SL, Kammula US, Restifo NP, et al: Cancer Regression in Patients After Transfer of Genetically Engineered Lymphocytes. Science 2006.

66. Pule MA, Savoldo B, Myers GD, Rossig C, Russell HV, Dotti G, Huls MH, Liu E, Gee AP, Mei Z, et al: Virus-specific T cells engineered to coexpress tumorspecific receptors: persistence and antitumor activity in individuals with neuroblastoma. Nat Med 2008, 14:1264-1270.

doi:10.1186/1479-5876-8-17

Cite this article as: Sasaki et al:: miR-17-92 expression in differentiated T cells - implications for cancer immunotherapy. Journal of Translational Medicine 2010 8:17. 